\title{
Use of protected areas for freshwater biomonitoring - case studies in Switzerland
}

\author{
Christopher T. Robinson, Michael Doering \& Laura Seelen
}

Keywords: bioassessment, Swiss National Park, macroinvertebrates, diatoms, stream

\section{Abstract}

The rapidity at which global landscapes are being transformed by environmental change has revived the importance of biological monitoring. Protected areas harbour some of the most biodiverse assemblages on the planet, typically show the least historical impacts from humans and likely represent areas showing natural patterns, process dynamics and fluctuations that can be compared with areas more directly impacted by humans, especially as the human population grows. This paper provides examples of different biomonitoring programmes in three protected areas in Switzerland, ranging from a large experimental flow program and recent land annex in the Swiss National Park, to a historical analysis of a designated floodplain of national importance. The data (1999-present) from the experimental flood study have documented substantial changes in biota that have occurred 7-10 years after the initial flood results as the system enters new ecological states. Monitoring of the land annex in the national park since 2000 has allowed documentation of temporal shifts in physico-chemistry and diatoms that were related to environmental changes in Alpine landscapes. The analysis of historical photo's of the protected floodplain showed the effects of earlier impacts on floodplain structure and function that are evident today. The results demonstrate the kinds of data that can be generated from biomonitoring programmes with different objectives and goals and how these data can be used to understand eco-evolutionary and ecosystem processes better in the face of rapid landscape transformation.
Profile

Protected Area

Swiss National Park

Urbach floodplain

Mountain range

Alps

Country

Switzerland

\section{Introduction}

Only recently has the importance of biomonitoring re-emerged, following a number of decades in which programmes were gradually reduced or even cut because of financial considerations and the rather shortsighted view that the data collected had little scientific value. There also was a general feeling that data ended up in low impact journals or, even worse, as reports in the so-called grey literature. Lately, however, a resurgence has occurred in which the number of papers being published using long-term data sets and analysed using robust meta-analytical statistics has grown (e.g. McCarthy et al. 2006). Further, resource managers and researchers have been challenged with providing insights and predictive forecasts on ecosystem changes resulting from the rapid transformations of landscapes from global environmental change (Clark et al. 2001; Hanson 2008). New technologies allow analysis of historical landscape patterns (Doering et al. in press) or assessment of landscapes using novel properties such as thermal imaging (Tonolla et al. 2010). Lastly, a variety of long-term databases are available and currently being used for analyses of global trends in the environment, freshwaters in particular (Dodds et al. 1997; Banner et al. 2009).

The objectives of freshwater biomonitoring are many. For instance, long-term biomonitoring is used to document changes in ecosystem properties over time (Smol \& Cumming 2000; Livingstone \& Adrian 2009). Biomonitoring is also necessary for assessing changes in streams and rivers following restoration measures (Melis 2011). This latter point is quite important because the number of restoration projects has increased tremendously in the last decade and is a current priority in most developed countries, especially in Europe with the implementation of the Water Framework Directive (e.g. Woolsey et al. 2007). Monitoring is imperative for documenting the success of restoration measures, as the costs of these measures are considerable and require major decisions on priorities regarding which systems to restore (Reichert et al. 2007). Biomonitoring in protected areas provides the best case scenario for understanding natural changes, dynamics, and fluctuations that can be compared to changes documented in regulated and restored ecosystems.

In this paper, we present three case studies of how biomonitoring, and the data generated, can be used to understand the dynamics and responses of freshwater ecosystems to changes in management and long-term changes in landscape properties. Examples are derived from protected areas within Switzerland, namely the Swiss National Park and the Urbach, a floodplain of national importance. All three protected areas are imbedded within human-dominated landscapes, thus increasing the comparability of data collected within each area. These three case studies document the simi- 


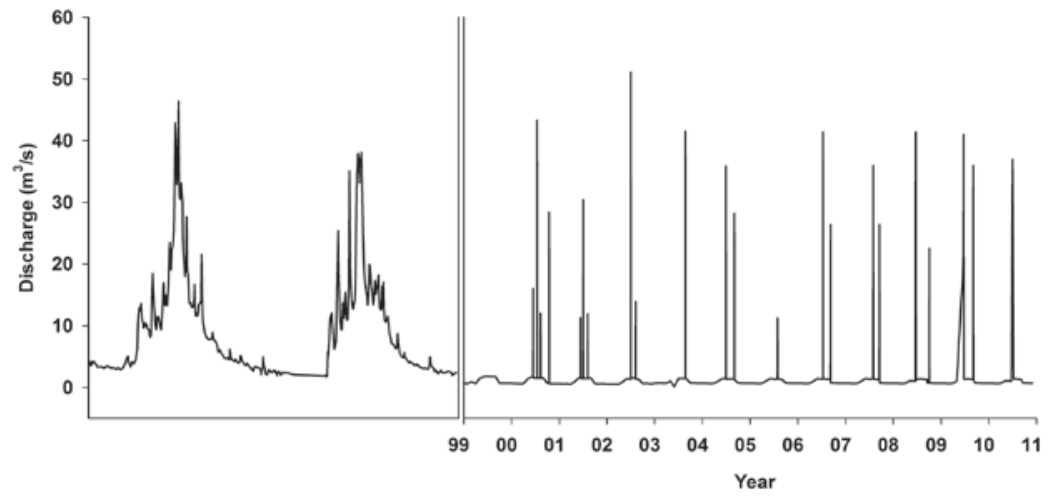

Figure 1 - Discharge regime of the Spöl river flowing through the Swiss National Park. The plot shows the typical flow regime before regulation, a year during flow regulation and the experimental floods from 2000 up to 2011.

larity, range and diversity of monitoring parameters for gaining important information to meet the specific goals of each monitoring programme. The use of similar monitoring parameters facilitates cross-analysis (meta) of long-term monitoring data sets, an important consideration when implementing new monitoring programmes both locally and globally.

\section{Case study I: Spöl river, Swiss National Park}

The Spöl River flows from Livigno reservoir on the Swiss-Italian border through a canyon-confined valley within the Swiss National Park for $\sim 5.7 \mathrm{~km}$ before entering the lower Ova Spin reservoir (10 11'22' E, $\left.46^{\circ} 36^{\prime} 38^{\prime \prime} \mathrm{N}\right)$. The climate is continental with low precipitation but high seasonal variation in temperature. Upland vegetation is dominated by coniferous forest (Picea excelsa, Pinus mugo) and alder (Alnus incana) is a common riparian tree. Elevation at the study reach about $2.3 \mathrm{~km}$ downstream of the dam is $1660 \mathrm{~m}$. Before regulation, the Spöl had a typical snow-melt / glacial-melt flow regime with high flows in summer and low flows in winter (Figure 1). The Spöl represents a protected area used as a long-term experimental study of flow regime changes on river ecosystems. The protected status facilitated the changes in flow regulations used to improve the ecological integrity of the river. Biomonitoring documented whether changes in flow resulted in the expected desired outcomes, which eventually were implemented in the flow management of the river.

The Spöl is part of a complex hydroelectric scheme (Scheurer \& Molinari 2003). Punt dal Gall dam became operational in 1970 and flow regulation decreased the annual average discharge in the river from 8.6 to $1.0 \mathrm{~m}^{3} / \mathrm{s}$. Regulated flows now average $0.55 \mathrm{~m}^{3} / \mathrm{s}$ in winter and $2.5 \mathrm{~m}^{3} / \mathrm{s}$ in summer using hypolimnetic water from the reservoir (Figure 1). This residual flow lacked power, thus the riverbed became clogged with fine sediments (Ortlepp \& Mürle 2003) and large pools formed upstream of lateral debris fans (Mürle et al. 2003). The regulated river also had dense algal mats, extensive moss beds, and an invertebrate com- munity dominated by Gammarus fossarum (Robinson et al. 2003). In 1996 the Engadine power company, the Swiss National Park, and state authorities agreed to use experimental floods to improve habitat conditions in the river (Scheurer \& Molinari 2003). The floods are cost neutral because of the network of reservoirs, aqueducts and power houses that allow re-allocation of water for power production while maintaining the residual flows (Robinson \& Uehlinger 2008). The experimental flood programme began in summer 2000 and, based on study results to date, is now included in the regulatory framework of the reservoir ( $\mathrm{T}$. Scheurer, personal communication).

Twenty-two separate floods have been released between 2000 and the end of 2010 following an adaptive management strategy based on biomonitoring results (Figure 1). The flood programme began with three floods each in 2000 and 2001, then alternating between two floods and a single flood per year from 2002 to 2005. After 2002, the June flood was eliminated, and in years of two floods, a high flow occurred in July $\left(>30 \mathrm{~m}^{3} / \mathrm{s}\right)$ with a smaller flow in late August / early September $\left(15-25 \mathrm{~m}^{3} / \mathrm{s}\right)$. A 4-day flushing flow was released from 19-22 June 2009 (peak flow of $41 \mathrm{~m}^{3} / \mathrm{s}$ ), and single floods were implemented in $2003\left(41.5 \mathrm{~m}^{3} / \mathrm{s}\right), 2005\left(11.2 \mathrm{~m}^{3} / \mathrm{s}\right)$, and $2010\left(37 \mathrm{~m}^{3} / \mathrm{s}\right)$. Except for the June 2009 flood, each flood lasted be-tween $6-8$ hours with the step-like rising and falling limb being controlled by the physical mechanics of the release valve.

\section{Long-term biomonitoring protocol}

A $200-\mathrm{m}$ long reach about $2.3 \mathrm{~km}$ downstream of the dam is being used for the long-term monitoring of the river. Discharge is recorded at the gauging station at Livigno dam by the Federal Office of Hydrology and Geology. A temperature logger (Minilog, Vemco Inc., Nova Scotia, Canada) was installed at the study site and records temperature at 1 -hour intervals. Temperature spot recordings are made on each visit as well (WTW LF340, Weilheim, Germany). The overall sampling frequency has varied between years, depending on time availability and specific needs of the study, but visits are usually made every 3-4 weeks when accessible for long-term monitoring purposes.

On each sampling visit, a 1-L water sample is collected for analysis of nitrate-nitrogen $\left(\mathrm{NO}_{3}-\mathrm{N}\right)$, soluble reactive phosphorus $\left(\mathrm{PO}_{4}-\mathrm{P}\right)$, dissolved organic carbon (DOC), and particulate organic carbon (POC) following methods detailed in Tockner et al. (1997). In the field, turbidity (nephelometric turbidity units; NTU) (Cosmos, Züllig AG, Switzerland), conductivity $\left(\mu \mathrm{S} / \mathrm{cm}\right.$ at $20^{\circ} \mathrm{C}$ ) (WTW LF340, Weilheim, Germany), and $\mathrm{pH}$ (WTW pH3110, Weilheim, Germany) are measured using portable meters.

Benthic macroinvertebrates are collected from riffle / run habitats on each visit $(\mathrm{n}=3)$ using a Hess sampler $\left(0.045 \mathrm{~m}^{2}, 250-\mu \mathrm{m}\right.$ mesh). Riffle/ run habitats are the most common habitat types in the river 
because it flows through a canyon-confined valley. Samples are stored in plastic bottles and preserved in the field with $70 \%$ ethanol. In the laboratory, macroinvertebrates are handpicked from each sample using a dissecting microscope at $10 \times$, identified to lowest practical taxonomic unit (usually genus) and counted. Periphyton and seston are also collected on each visit, but these data are not used in the present paper for discussion (see Uehlinger et al. 2003 for details and some early results). The various parameters measured in this study were used to provide a holistic coverage of possible changes in the river system resulting from the changes in flow.

\section{Highlights of results}

As expected, water physico-chemistry remained fairly stable during the study period due to the hypolimnetic release of water from the reservoir. Water $\mathrm{pH}$ averaged 7.5 (0.4 SD), mean conductivity 255 (47 SD) $\mu \mathrm{S} / \mathrm{cm}$, mean nitrate-N 258 (47 SD) $\mu \mathrm{g} / \mathrm{L}$, and mean soluble reactive phosphorus 1.0 (1.5) $\mu \mathrm{g} / \mathrm{L}$. Mean temperature was $7.6^{\circ} \mathrm{C}$ and ranged from $1-2{ }^{\circ} \mathrm{C}$ in winter to $10-12{ }^{\circ} \mathrm{C}$ in summer. Dissolved organic carbon averaged $0.9(0.5 \mathrm{SD}) \mathrm{mg} / \mathrm{L}$ and mean particulate organic carbon averaged 0.7 (1.2 SD) $\mathrm{mg} / \mathrm{L}$.

A multivariate analysis (NMDS) based on taxon relative abundances of macroinvertebrates revealed significant temporal shifts in community assembly (Figure 2). Assemblage composition was similar in 1999 and 2000, and then a shift occurred in 2001, with assemblages being grouped from 2003 to 2006. Another shift occurred in 2007, with assemblages grouping together from 2007 to 2010 (stress =11.5). These results indicate an early period of transition in community assembly between 2001-2003 and a later shift between 2006-2007. The overall results suggest a system slowly returning to a more alpine nature in ecological assemblages, aspects not evident from short-term monitoring results.

Plotting of community indices such as taxonomic richness also shows these shifts in assemblage struc-

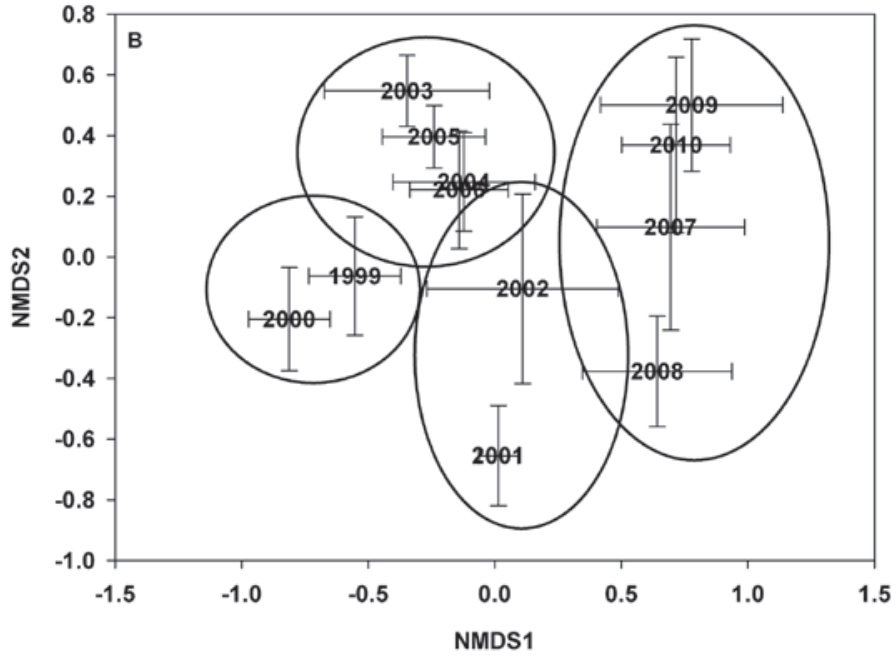

Figure 2 - Plot of an NMDS analysis based on the relative abundances of invertebrate taxa from samples grouped during each year of the project. Bars represent the average values for each year and the standard deviations.

ture over time. The system first experienced a loss in richness as the floods reduced the abundances of taxa ill-suited to resist flood disturbances (Figure 3). Species richness began to increase again in later years as novel taxa started to colonize and inhabit the system. Plotting of individual taxa also shows that some species were prone to flood disturbance with lower abundances or even being lost from the system, while others increased in abundance, and others only became common later in the flood programme (see Robinson \& Uehlinger 2008). Only through long-term monitoring could these different response patterns for different taxa be observed, especially species that are only recently colonizing the system. These longterm data suggest the system is still undergoing biotic changes in response to the flood programme and changes in the habitat template of the river, something that could not be demonstrated without biomonitoring.

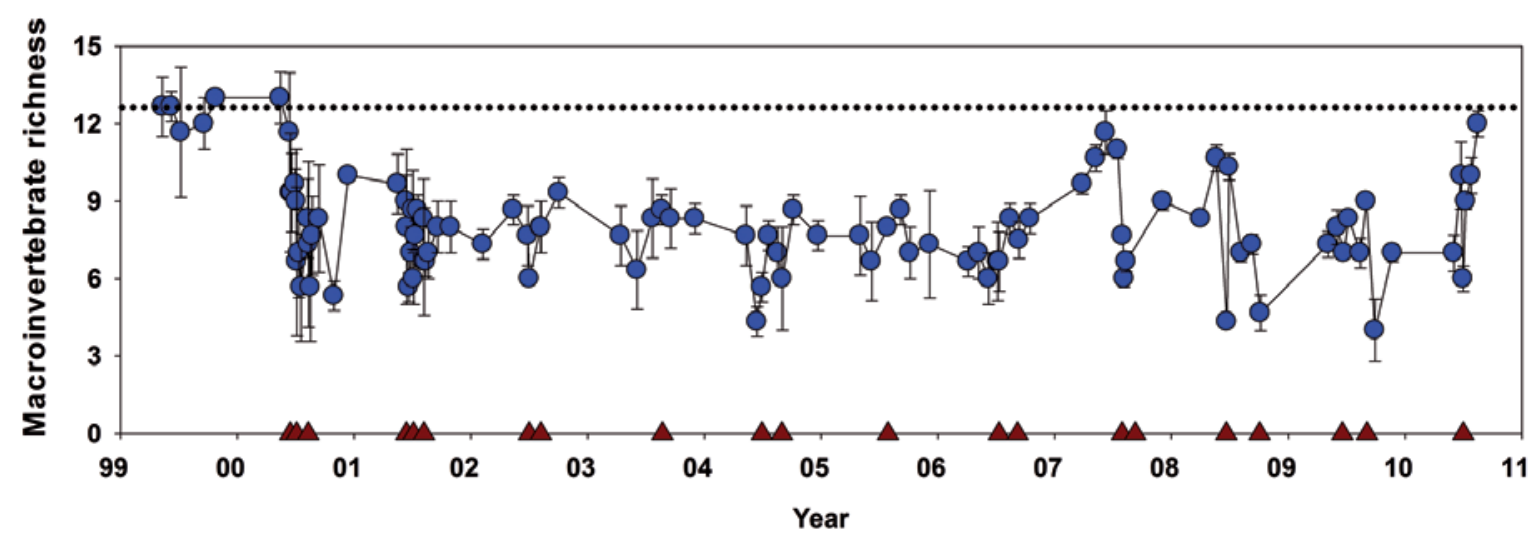

Figure 3 - Plot of changes in taxonomic richness in the Spöl river during the study period. Each point represents the mean taxonomic richness $(n=3,+S E)$. The triangles show the date for each flood, and the dotted line shows the average taxonomic richness for 1999 before the first experimental flood. 


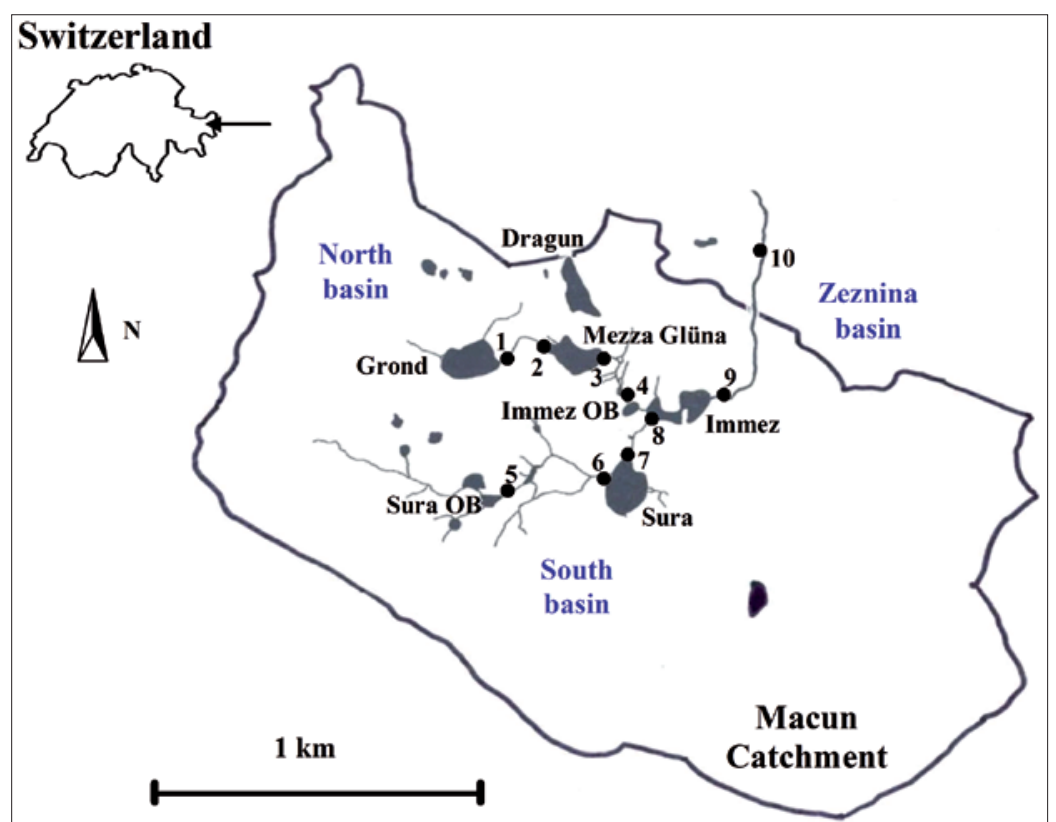

Figure 4 - Schematic map of the Macun lakes area with numbers showing the sample site locations in each basin and on the outlet stream. Map modified from Robinson \& Matthaei (2007). line, and most terrestrial vegetation is typical alpine grasses and low lying herbs with areas of bare rock being common.

\section{Long-term biomonitoring protocol}

Biomonitoring of streams began in September 2001, followed by collections in late July or early August from 2002 to the present. For streams, 10 sites are sampled on each date: four in the north basin, four in the south basin, and two in the outlet stream (Figure 4). The sites are situated at the inlets and outlets of the prominent lakes in each basin along a longitudinal gradient. Lake Immez is located at the confluence of the north and south drainage channels, and site 9 was at its outlet stream. Meltwater from a large rock glacier enters the outlet stream between stream sites 9 and 10. Readers are referred to Robinson and Oertli (2009) for information regarding the monitoring of the lakes. For the purpose of this paper, the monitoring of diatoms are emphasized and readers are referred to Robinson and Kawecka (2005) for detailed results of the long-term findings.

A 1-L water sample is collected from each site on each visit for analysis of nitrate- $\mathrm{N}$, particulate $\mathrm{N}(\mathrm{PN})$, particulate $\mathrm{P}(\mathrm{PP})$, dissolved organic matter (DOC), and particulate organic matter (POC) following methods in Robinson \& Matthaei (2007). On each visit, spot measures are taken around mid-day for temperature, conductivity, turbidity and $\mathrm{pH}$ using field-portable meters (see above).

In conjunction with other biotic measures (see Robinson \& Oertli 2008), diatoms also are sampled from each site on each visit, beginning in September 2001 and then in late July or early August each year since then. One set of samples was also collected in September 2002. From each site, five rocks are randomly collected along a $10 \mathrm{~m}$ reach. The periphyton layer on the surface of each rock is scrubbed with a brass brush and the slurry rinsed into a plastic container. A subsample $(\sim 4 \mathrm{ml})$ from each slurry is then combined in a $20-\mathrm{ml}$ plastic vial, preserved with $2 \%$ formalin, and taken to the laboratory. In the laboratory, each sample is macerated in a chromic acid cleaning solution $(3: 1 \mathrm{v} / \mathrm{v}$ of sulphuric acid and potassium dichromate) for $1-2$ days, and then washed by centrifugation. Diatoms are embedded permanently on glass slides with the synthetic resin Pleurax, having a reflective index of 1.75. Slides for diatoms are examined using a Nikon microscope (Eclipse 600) and, when necessary, by scanning electron microscopy (SEM; JEOL JSM $35 \mathrm{CF}$ ). A minimum of 250 diatom valves are counted and identified along random transects from each slide based on the keys of Krammer \& LangeBertalot (1991, 1999a, b, 2000), Round et al. (1990), Lange-Bertalot \& Moser (1994), and Lange-Bertalot \& Metzeltin (1996). mer to below $-15^{\circ} \mathrm{C}$ in winter based on records from a nearby climate station (Buffalora) $\sim 14 \mathrm{~km}$ southeast of Macun. Bedrock geology is slow-weathering crystalline (ortho-gneiss) rock. The area is above the tree 
Highlights of results

Temporal changes in temperature and dissolved nitrogen are used to illustrate the shift in physico-chemistry of the streams from 2004 to 2005 (Figure 5). Temperature generally increased for all sites for years before and after 2004, but sites in the south basin showed a greater average increase in temperature by up to $4{ }^{\circ} \mathrm{C}$. In contrast, nitrogen generally decreased between these periods, and was more pronounced (by up to $50 \mu \mathrm{g} / \mathrm{L})$ in the north basin sites and higher order south basin sites. Little change in dissolved nitrogen was observed in site 5 and site 10, both being directly influenced by inputs from rock glaciers. Robinson \& Oertli (2009) provide details on long-term changes in the physico-chemistry and biota in the streams and lakes. These increases in temperature are occurring throughout the Alps and show the sensitivity of alpine waters to environmental change.

An example from the diatom monitoring for 2001 and 2007 shows shifts in assemblage structure in south basin streams that reflects these changes in environmental conditions (Figure 6). An even more dramatic change in assemblage structure was observed at the outlet stream site called Zeznina. The monitoring data for diatoms have revealed substantial differences between the north and south basins that reflect the differences in water physico-chemistry between the two basins, along with differences in the outlet stream that reflects the input of water from a large rock glacier (see Robinson \& Kawecka (2005) for a detailed statistical assessment of temporal changes in the diatom assemblages). Although both alpine basins are relatively oligotrophic, the diatom results show that changes in water chemistry are apparent and measurable through the biomonitoring programme of biota.

High-alpine freshwaters are sensitive to environmental changes that are occurring in today's landscapes, and these changes are clearly documented in the changes in diatom assemblage structure. Longterm records are needed and obviously important for documenting these changes. Diatoms are good indicators of environmental change, such as temperature and water quality, as they are sensitive to these changes and respond relatively rapidly. This case study emphasizes the importance of including a variety of parameters to meet specific goals of a biomonitoring programme, long-term change in this particular programme.

\section{Case study III: Urbach floodplain - Berner Oberland}

The Urbach river floodplain $(800-900 \mathrm{~m})$ is in the canton of Bern, Switzerland. The $3.4 \mathrm{~km}$ long and up to $600 \mathrm{~m}$ wide floodplain (ca. $125 \mathrm{ha}$ ) is bordered by canyon-constrained knick-points at both ends of the floodplain. A steep rockface on the left side of the river confines the valley to the east, whereas the right side of the floodplain has grassland and pasture areas bordered by mountain slopes (Figure 7). The geology

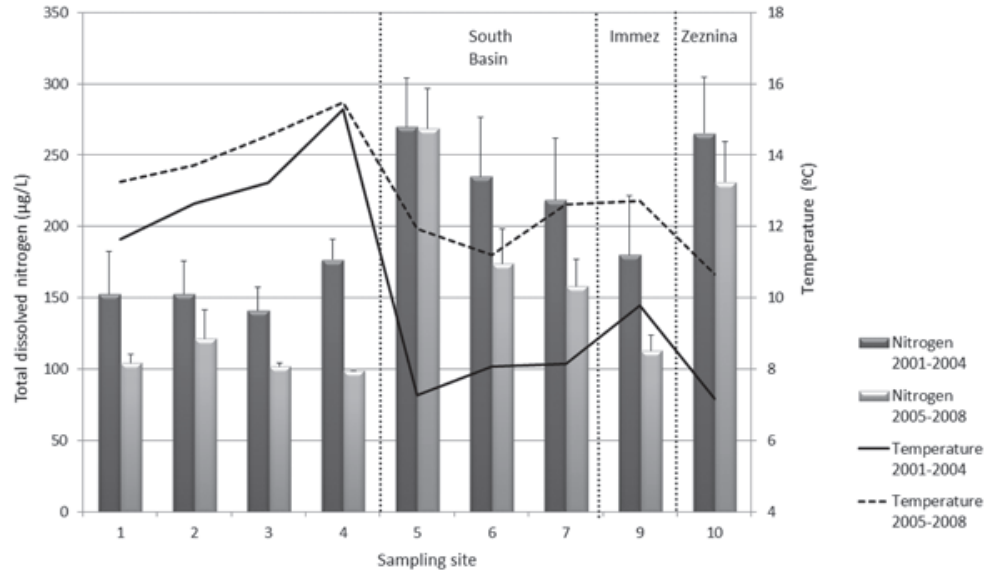

Figure 5 - Changes in temperature and nitrogen levels in stream water in the two main basins and the outlet sites (numbers 9 and 10 on the map in figure 4). See Robinson \& Oertli (2009) for a more detailed assessment of the monitoring programme for Macun.

is mostly limestone and crystalline rocks. The floodplain itself contains the main river channel, side channels, islands, open gravel bars, vegetated gravels with successive shrub vegetation (Salix spp.), and mature forest mainly dominated by Alnus incana. Livestock (cows, sheep) grazing also occurs in the floodplain.

The discharge regime of the Urbach is glacio-nival with highest discharge during snow/glacier melt in spring/summer. Precipitation events often result in high flows, although flow is constrained by hydrological impairments. In 1950 dam construction in the headwaters (Gauli Glacier), about $6 \mathrm{~km}$ upstream of the study area, formed Lake Mattenalp (1875 m) where about $30 \%$ of the average annual flow of the river is abstracted for power production. Starting in 1950, several levees for flood protection were installed in the active part of the floodplain. This case study highlights the use of historical images to facilitate potential management goals to conserve and sustain a protected area under ever increasing demands for human use. The historical images will be used to better understand biomonitoring results from a recently initiated bioassessment programme.

\section{Long-term assessment of floodplain features}

We used historical aerial images (1940, 1960, 1969, $1977,1986,1998,2007)$ to map the different habitat types of the floodplain over time (Figure 7). All images were taken between July and August when river discharge was similar and below bankfull. Aerial images were scanned at $600 \mathrm{dpi}$ and georectified to a referenced 2007 digital ortho-photo provided by vendors using ArcGIS 9.3 (ESRI Redlands, California, USA). During image rectification, each photograph was resampled to a $0.5 \mathrm{~m}$ resolution for consistency among all images and resulted in a root mean square error of $<1.4 \mathrm{~m}$ for all images.

Six typical floodplain habitats (i.e. mature forest, gravel, vegetated gravel, islands, water, pasture, and grassland) were quantified for each aerial image. Habitats were delineated by digitizing manually drawn 


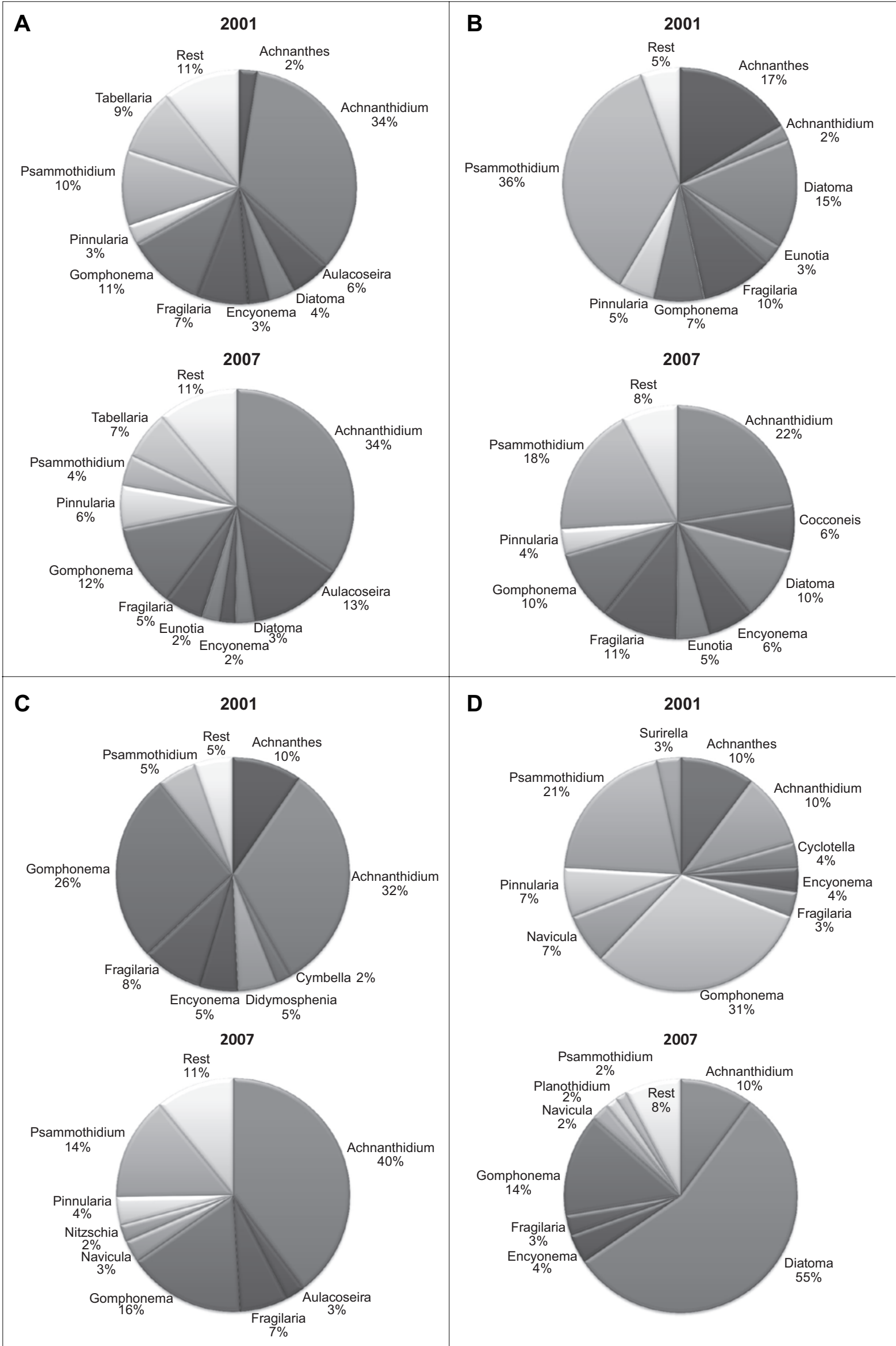

Figure 6 - Pie charts of diatom assemblages (only main groups presented) for 2001 and 2007 from (A) north basin sites combined, (B) south basin sites combined, (C) Immez outlet (site 9 on map), and (D) Zernina (site 10 on map). 


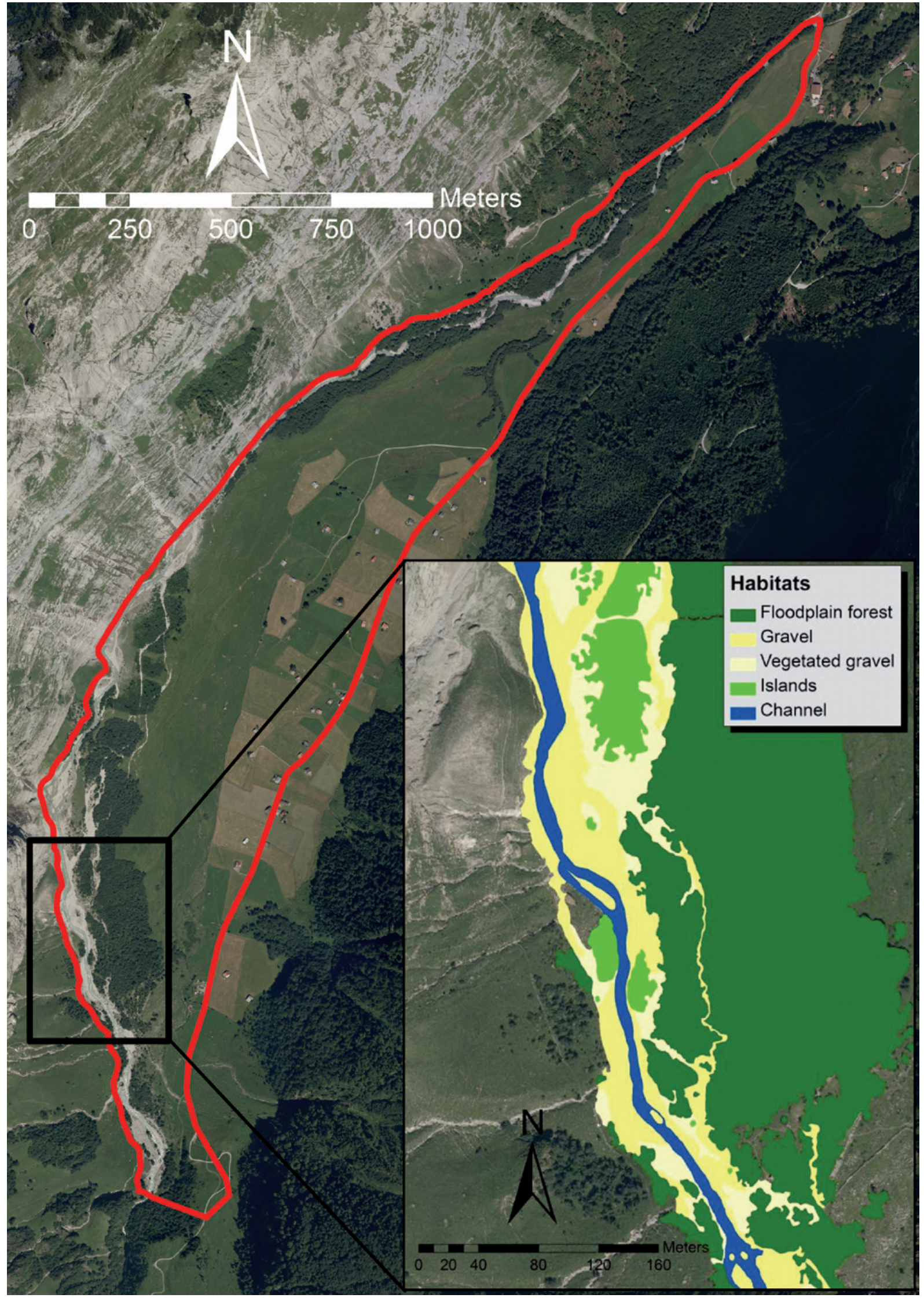

Figure 7 - Map of the Urbach floodplain. The red line delineates the floodplain area used for the quantification of changes in habitat abundance of different habitat types (see inlet). The Sandey is a national floodplain of importance within Switzerland. Source: Bundesamt für Landestopografie. 


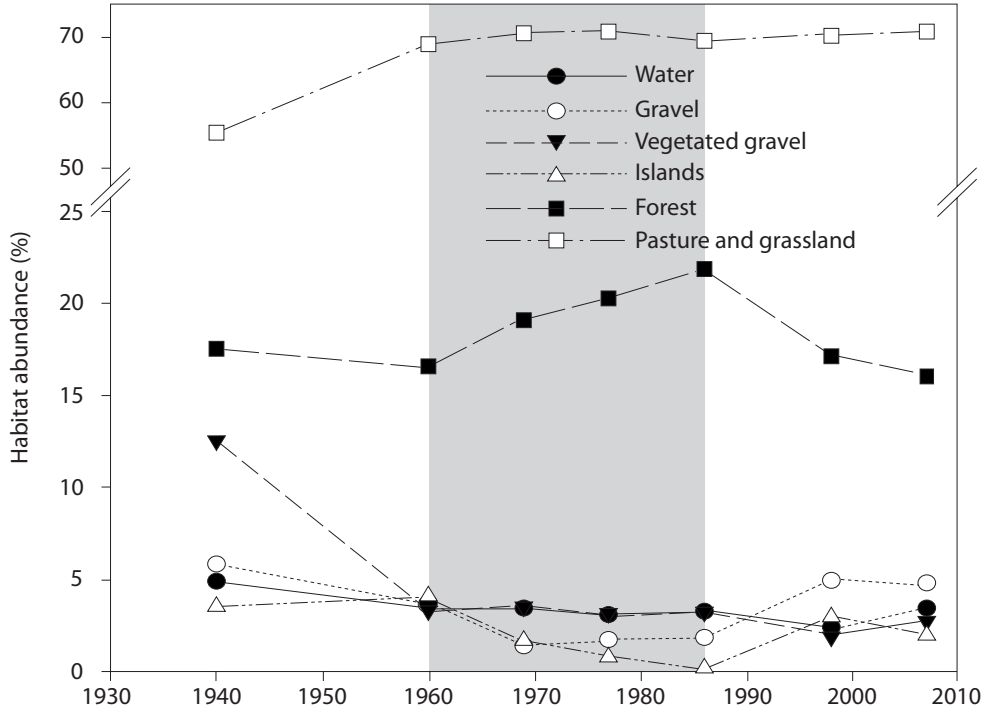

Figure 8 - Plot of the change in habitat types based on analysis of historical aerial images (see Doering et al., in press, for more details regarding the floodplain).

polygons around habitat elements in ArcGIS. From the different vector layers, we calculated the relative proportion of each habitat type as a percentage of total floodplain area to quantify changes in the relative abundance of habitat types between sequential aerial photos covering ca. 70 years of change. Readers are referred to Doering et al. (in press) for a detailed assessment of the results.

\section{Highlight of results and implications}

Results show that over $48 \%$ of the total floodplain area changed at least once and approximately $5 \%$ of the floodplain changed habitats at least four times during the study period (Figure 8). The results also show the occurrence of three main time intervals of change in habitat abundance (floodplain percentages). First, a period from 1940 to 1960 , when approximately $32 \%$ of all habitat types changed spatially. Second, a period from 1960 to 1986, when habitat types overall changed between 15 and 11\%. Lastly, a third period from 1986 to 2007 , when changes in habitat types ranged between 18 and 16\%, but showing a different developmental pattern compared to before 1986. For the entire study period (1940 to 2007), most habitat types decreased in relative abundance, ranging from $9 \%$ (forest) to $78 \%$ (vegetated gravel), whereas pasture and grassland showed an increase of $28 \%$.

Natural floodplains are spatially heterogeneous and dynamic ecosystems, but at the same time, a highly endangered landscape feature due to climate change and human impacts such as water storage, flood control and hydropower production. Despite their highly dynamic nature, the relative abundance of different habitat types in natural floodplains seems to remain more or less constant over ecological time periods and is referred to as the shifting mosaic steady state concept (Bormann \& Likens 1979; Stanford et al. 2005). We used this concept to assess spatio-temporal changes in relative habitat abundance and channel complexity of an alpine floodplain from its near-natural state in 1940 , before water abstraction and levee construction, until 2007 using historical aerial images. Our results were contrary to expectations of the shifting mosaic steady state concept, thereby demonstrating its potential as an indicator of landscape transformation and human impacts on floodplain ecosystems. This case study shows the potential of incorporating historical images in biomonitoring programmes, which may prove beneficial in the conservation and management of protected areas.

\section{Discussion}

These three case studies clearly document the kinds of data that can be generated and used through longterm biomonitoring in protected areas. Although the goals of each biomonitoring programme differ (restoration success, long-term change, historical analysis), all three demonstrate the use of similar biomonitoring parameters for gaining the necessary information for managers and understanding the long-term changes occurring in the different catchments. Using a suite of parameters in biomonitoring provides data that can be used for different purposes or increase understanding of observed changes. Different data collected can also be applied to answering diverse questions, questions that may differ in relevance to a particular parameter being measured. Furthermore, there is a greater chance that the data generated can be used in crosscomparisons and meta-analysis among systems. Most long-term biomonitoring programmes also acquire other multiple factors, e.g. landscape transformation or environmental changes, over time that benefit from a multivariate approach to better elucidate and explain their eco-evolutionary effects of monitored ecosystems.

The case studies described in this paper show the variety of uses of long-term monitoring. A key point is that although similar parameters are being measured, they are being used to test whether management goals in each system are being met. The Spöl experiment shows how long-term monitoring can be used to test whether management decisions result in expected ecological changes. The results show that the system is still undergoing biological changes as it shifts through alternate states. The protected status of the Swiss National Park facilitated this long-term ecosystem experiment that would have been difficult in other regulated rivers. The data generated have assisted resource managers globally towards changing flows in other rivers for ecological improvement (see Melis et al. 2010). The Macun lakes ecosystem shows how to successfully implement a monitoring programme in a protected area to gain the maximum information from a relatively small spatial area with a minimum amount of effort. This system provides baseline monitoring data that can be used across many alpine landscapes in Europe and potentially globally. The diatom results are 
but one biological feature being measured in the system, but show that environmental change is occurring in alpine landscapes. The Urbach study shows the use of historical images for assessing landscape change in a protected area; data that can be cross-compared with other landscapes (impacted or not) to gain a more complete picture of long-term environmental change under ever-increasing human impacts. The results from the historical photo analysis has shown possible options for restoring some of the functional features of this valuable floodplain without imposing on the socio-economy of the region.

Protected areas of the world are under ever-increasing pressures from multiple sources, acting both locally and globally (MEA 2005). Protected areas also carry the legacies of past landscapes and climates, and the burden of future large-scale changes (e.g. Hanson 2008). Long-term biomonitoring is imperative if scientists, resource managers, and the public are to benefit from the past and future ecological knowledge archived in our protected areas. Long-term biomonitoring of protected areas gives us important data for which to test scientific principles and learn from management actions, akin to large-scale ecological experiments (Konrad et al., in press). The case studies presented in this paper are but a small subset of the numerous long-term biomonitoring programmes in place throughout the world, but document the over-riding importance of using protected areas as ecosystems for maintaining long-term biomonitoring programmes. Protected areas house the biological information needed to better understand changes occurring in human dominated landscapes, making biomonitoring programmes ever more important.

\section{Acknowledgements}

We thank C. Jolidon, S. Blaser, and R. Illi for field assistance and processing the various benthic and water samples for each of the study systems. We thank B. Kawecka for identifying the diatoms from the Macun lakes, M. Blaurock for image analyses from the Urbach floodplain project. Partial funding for the different studies came from the Swiss National Park and Kraftwerke Oberhasli (KWO). Some of the methods and results have been presented more formally in other papers for each of the case studies discussed above. Two anonymous reviewers provided constructive comments that improved the paper. Data collected for the Spöl project and Urbach floodplain were part of pilot site information for the Alp-Water-Scarce project (Alp-Water-Scarce: Interreg IV B, Alpine Space Programme, project 5-1-3-F).

\section{References}

Banner, E., A. Stahl \& W. Dodds 2009. Stream discharge and riparian land use influence in-stream concentrations and loads of phosphorus from cen- tral plains watersheds. Environmental Management 44: 552-565.

Bormann, F.H. \& G.E. Likens. 1979. Pattern and process in a forested ecosystem. New York.

Clark, J., S. Carpenter, M. Barber, S. Collins, A. Dobson, J. Foley, D. Lodge, M. Pascual, R. Pielke \& et al. 2001. Ecological forecasts: an emerging imperative. Science 293: 657-660

Doering, M., M. Blaurock \& C.T. Robinson. Landscape transformation of an alpine floodplain influenced by humans: historical analyses from aerial images. Hydrological Processes. In press.

Dodds, W., V. Smith \& B. Zander. 1997. Developing nutrient targets to control benthic chlorophyll levels in streams: a case study of the Clark Fork River. Water Research 31: 1738-1750.

Hanson, P.C. 2008. New ecological insights through the Global Lake Ecological Observatory Network (GLEON). Ecological Science 27: 300-302.

Konrad, C., J.D. Olden, D.A. Lytle, T. Melis, J.C. Schmidt, E. Bray, M. Freeman, K. Gido, N. Hemphill, M. Kennard, L. McMullen, M. C. Mims, M. Pyron, C. T. Robinson, J. G. Williams. In press. Large-scale flow experiments in managing water resources. BioScience.

Krammer K. \& H. Lange-Bertalot 1991. Bacillariophyceae. Achnanthaceae. In: Ettl H., G. Gärtner, J. Gerloff, H. Heynig \& D. Mollenhauer (eds.), Süsswasserflora von Mitteleuropa 2/4. Stuttgart, Jena.

Krammer, K. \& H. Lange-Bertalot 1999a. Bacillariophyceae. Naviculaceae. In: Fischer G., H. Ettl, J. Gerloff, H. Heynig \& D. Mollenhauer (eds.), Süsswasserflora von Mitteleuropa 2/1. Heidelberg, Berlin

Krammer, K. \& H. Lange-Bertalot 1999b. Bacillariophyceae. Bacillariaceae, Epithemiaceae, Surirellaceae. In: Fischer G., H. Ettl, J. Gerloff, H. Heynig \& D. Mollenhauer (eds.), Süsswasserflora von Mitteleuropa 2/2. Heidelberg, Berlin.

Krammer, K. \& H. Lange-Bertalot 2000. Bacillariophyceae. Centrales, Fragilariaceae, Eunotiaceae. In: Fischer G., H. Ettl, J Gerloff, H. Heynig \& D. Mollenhauer (eds.), Süsswasserflora von Mitteleuropa 2/3. Heidelberg, Berlin.

Lange-Bertalot, H. \& D. Metzeltin 1996. Indicators of Oligotrophy - 800 taxa representative of three ecologically distinct lake types, Carbonate buffered Oligodystrophic - Weakly buffered soft waters. In: Lange-Bertalot, H. (ed.), Iconographia Diatomologica 2.

Lange-Bertalot, H. \& G. Moser 1994. Brachysira, Monographie der Gattung und Naviculadicta nov. gen. In: Lange-Bertalot, H. (ed.), Bibliotheca Diatomologica 29. Berlin - Stuttgart

Livingstone, D.M. \& R. Adrian 2009. Modeling the duration of intermittent ice cover on a lake for climate-change studies. Limnology and Oceanography 54: 1709-1722.

McCarthy, J.M., C.L. Hein, J.D. Olden \& M.J. Vander Zanden 2006. Coupling long-term studies with metaanalysis to investigate impacts of non-native crayfish on zoobenthic communities. Freshwater Biology 51:224-235. 
Melis, T.S. (ed.) 2011. Effects of three high-flow experiments on the Colorado River ecosystem downstream from Glen Canyon Dam, Arizona. U.S. Geological Survey Circular 1366.

Millennium Ecosystem Assessment (MEA) 2005. Ecosystems and human well-being: synthesis. Washington, DC.

Mürle, U., J. Ortlepp \& M. Zahner 2003. Use of experimental flooding to enhance river integrity below a large dam: sediment processes and changes in geomorphology, habitat structure and riparian vegetation. Aquatic Sciences 65: 191-198.

Ortlepp, J. \& U. Mürle 2003. Effects of experimental flooding on brown trout (Salmo trutta fario L.): the Spöl River, Swiss National Park. Aquatic Sciences 65: 232-238.

Reichert, P., M. Borsuk, M. Hostmann, S. Schweizer, C. Sporri, K. Tockner \& B. Truffer. 2007. Concepts of decision support for river rehabilitation. Environmental Modelling and Software 22: 188-201.

Robinson, C.T. \& B. Kawecka 2005. Benthic diatoms of an Alpine stream/lake network in Switzerland. Aquatic Sciences 67: 492-506.

Robinson, C.T. \& S. Matthaei 2007. Hydrological heterogeneity of an Alpine stream/lake network in Switzerland. Hydrological Processes 21: 3146-3154.

Robinson, C.T. \& B. Oertli 2009. Long-term biomonitoring of Alpine waters in the Swiss National Park. eco.mont 1 (1): 23-34.

Robinson, C.T. \& U. Uehlinger 2008. Experimental floods cause ecosystem regime shift in a regulated river. Ecological Applications 18: 511-526.

Robinson, C.T., U. Uehlinger \& M.T. Monaghan 2003. Effects of a multi-year experimental flood regime on macroinvertebrates downstream of a reservoir. Aquatic Sciences 65: 210-222.

Round, F.E., R.M. Crowford \& D.G. Mann 1990. The Diatoms, Biology and morphology of the genera. Cambridge.

Scheurer, T. \& P. Molinari 2003. Experimental floods in the River Spöl (Swiss National Park): framework, objectives and design. Aquatic Sciences 65: 183-190.

Smol, J. \& B. Cumming 2000. Tracking long-term changes in climate using algal indicators in lake sediments. Journal of Phycology 36: 986-1011.

Stanford, J.A., M.S. Lorang \& F.R. Hauer 2005. The shifting habitat mosaic of river ecosystems. Verbandlungen der Internationalen Vereinigung für Theoretische und Angewandte Limnologie 29: 123-136.

Tonolla, D., V. Acuna, U. Uehlinger, T. Frank \& K. Tockner 2010. Thermal heterogeneity in river floodplains. Ecosystems 13: 727-740.

Uehlinger, U., B. Kawecka \& C.T. Robinson 2003. Effects of experimental floods on periphyton and stream metabolism below a high dam in the Swiss Alps (River Spöl). Aquatic Sciences 65: 199-209.

Woolsey, S., F. Capelli, T. Gonser, E. Hoehn, M. Hostmann, B. Junker, A. Paetzold, C. Roulier, S. Schweizer, S. Tiegs, K. Tockner, C. Weber \& A. Peter 2007. A strategy to assess river restoration success. Freshwater Biology 52: 752-769.

\section{Authors}

\section{Christopher T. Robinson}

is a senior researcher in the Department of Aquatic Ecology (ECO), Eawag, specializing in general stream ecology. His primary research entails the ecology of alpine streams with a focus on macroinvertebrates and algae. He is a member of the research commission of the Swiss National Park.

\section{Michael Doering}

is a researcher at ECO, Eawag working on the structure and function of riverine floodplains. His current research programme incorporates the use of remote sensing tools for assessing floodplain function along with field assessments of microbial activity.

\section{Laura Seelen}

was a masters student in ECO during the writing of the manuscript, and summarized the temporal trends in diatoms of the Macun lakes area as part of her thesis. She is currently finalizing her masters curriculum at the Department of Environmental Sciences, Radboud University Nijmegen, Belgium. 